\title{
Patient perceptions on hospital food service at Teaching Hospital, Karapitiya
}

\author{
Fernando GHS ${ }^{1}$, Wijesinghe $\mathbf{C} \mathbf{J}^{2}$ \\ ${ }^{\prime}$ Base Hospital, Udugama, Galle, ${ }^{2}$ Department t of Community Medicine, Faculty of Medicine, University of \\ Ruhuna, Galle, Sri Lanka. \\ Correspondence: Dr. G H S Fernando \\ e-mail: ghsfernando@gmail.com
}

\begin{abstract}
Background: Hospital diet is an integral part of the management of in-ward patients. The quality of hospital food plays a major role in determining the overall satisfaction of patients with regards to their hospital stay.

Objective: To investigate the level of patient satisfaction with regards to the diet supplied at Teaching Hospital (TH), Karapitiya.

Methods: A descriptive, cross sectional study was conducted among 316 patients who received inward treatment at TH Karapitiya and consumed hospital diet. Data were collected using an interview-administered questionnaire and analyzed using SPSS statistical software.

Results: During the study period, only $27 \%$ of the in-ward patients consumed hospital diet. Of 316 included in the analysis, 13.6\% rated hospital diet "good", 59.7\% "fair", and 26.6\% "unsatisfactory". Patients were satisfied with the quantity of all types of food provided (above 85\%), time of food distribution (90\%), temperature of food $(85 \%)$ and texture $(86 \%)$. However, $31 \%$ of patients were unsatisfied with taste, $40 \%$ were unsatisfied with the smell of food and $29 \%$ were unsatisfied with the diversity of food provided. No significant association was found between overall satisfaction regarding food service and the patients' age, gender, ethnicity, educational level or length of hospital stay.
\end{abstract}

Conclusions: Patient perception on hospital food service at TH, Karapitiya was mostly favourable although patients were less satisfied about the quality of food. The proportion who consumed hospital food was low. Attempts must be taken to enhance the taste, smell and the diversity of food provided.

Key words: Hospital food service, hospital diet, patient satisfaction, food consumption

\section{Introduction}

Hospital diet is an essential component of patient recovery and well being (1). Diet consumed during hospital stay forms an integral part of patient management, therefore provision and consumption of a balanced diet is essential to speed up the recovery. These meals can provide a nutritional model for patients requiring dietary management, when tailored to their specific health conditions. Hence, every hospital food service must target to provide food that meets nutritional requirements, satisfies the patient and are microbiologically safe (2).

The quality of the food served while in the hospital plays a major role in patients' satisfaction with their overall hospital experience (3). It is reported that in-patients evaluate food service quality based on various factors such as taste, texture, variety, nutritional quality, sanitation, temperature, portion size, meal time, and servers' characteristics (4-6). 
Therefore, the attitude and the satisfaction of patients regarding hospital food service depend largely on these factors.

Despite its role as an essential contributor for recovery of patients, hospital food has a wide reputation for being tasteless, overcooked and unappetizing (7). Improvement of hospital food services remains a constant challenge due to many tangible and intangible aspects related to quality, ranging from menu items, portion size, taste, temperature, texture and variety of food to tray presentation, sanitation, offering nutritional information and responsiveness to food problems (812).

According to the Hospital Manual published by the Ministry of Health, Sri Lanka a patient's diet for a day is the entire requirement of food for a period of 24 hours, starting from 12 noon on a particular day to 12 noon of the following day (13). Medical Officer in charge has to determine the diet as it is regarded as a part of the management. All government hospitals in Sri Lanka provide diet free of charge to in-ward patients. Some patients, however, prefer food brought from their homes. A situational analysis performed by the principal investigator in four major hospitals in Galle and Ratnapura districts revealed that only a limited number of in-ward patients consumed hospital food: $25 \%$ in Teaching Hospital, Karapitiya, 12\% in Teaching Hospital, Mahamodara, $30 \%$ in General Hospital, Ratnapura and $20 \%$ in Base Hospital, Embilipitiya (unpublished data). The major reasons for poor consumption according to the key informants were tastelessness, unpleasant aroma of food and shyness to eat hospital food.

Regular attempts to review the quality and patient satisfaction of hospital food are of paramount importance to reap the benefits of this service. Conducting research on above aspects is mandatory to identify the deficiencies in the hospital food service and to explore the expectations of consumers with regards to the standards of meals provided to them. Such measures are useful in improving overall patient satisfaction and to prevent plate wastage due to poor meal quality. This study was conducted to assess the patient perceptions on hospital food with regard to menu, amount, hygiene, timeliness, taste and texture.

\section{Methodology}

This study was a descriptive, cross-sectional study, conducted at the Teaching Hospital (TH), Karapitiya which is the only tertiary care institution in southern Sri Lanka. Study sample included patients who received in-patient care from the medical, surgical, eye, Ear, Nose and Throat (ENT), neurosurgical and orthopedic wards and consumed hospital food during a period of 3 months from $25^{\text {th }}$ July 2013. A total of 316 patients were enrolled to the study and this included only the patients who consumed a normal hospital diet and could understand and respond to the questionnaire. Critically ill patients and those who were not on normal diet were excluded.

A pre-tested, interview-administered questionnaire was used to collect data on client satisfaction with regards to hospital food service. Data on basic sociodemographic profile of the participants were also collected. All data were collected by the principal investigator in order to minimize the interviewer bias. Informed consent was obtained from the eligible patients before data collection. Ethical approval for the study was obtained from the Ethical Review Committee, Faculty of Medicine, and University of Colombo. Institutional approval was obtained from the Director, TH, Karapitiya. Chi-squire test was used to determine the statistical significance of associations between variables. A probability level of 0.05 was considered as the critical value for statistical significance.

\section{Results}

A total of 316 patients on normal hospital diet were interviewed on perceived satisfaction with regards to hospital diet. During the study period, only $27 \%$ of the inward patients consumed hospital diet (Number of patients who consumed hospital diet/ average mid night total ${ }^{*} 100$ ). Characteristics of the study participants are given in Table 1.

In reporting the adequacy of the food provided, nearly $91 \%$ of the respondents stated that rice was adequately supplied. Approximately $85 \%$ were satisfied with the amount of fish given. Some patients had not received certain food items despite their requests (e.g. about $23.7 \%$. respondents stated that they did not receive fish even though they requested a fish diet). Overall, the proportion of 
patients who did not consume the different types of food provided ranged from $5 \%$ to $30 \%$. Patients' responses on the adequacy of the meals and the proportion who consumed different types of food are summarized in the Table 2.

Patients' views on taste, smell, texture and diversity of the food were studied to determine the perceived level of satisfaction with regards to the quality of hospital diet. Approximately $30 \%$ of the patients reported that the taste was not satisfactory and $40 \%$ said that the smell was unsatisfactory. The majority were satisfied with the texture, temperature and the timeliness of the food provided. However, over 26\% mentioned that the overall quality of the food was unsatisfactory. The level of patient satisfaction regarding the different aspects of hospital food service is shown in Table 3 .
About 33.5\% ( $\mathrm{n}=106)$ of the patents mentioned that they did not consume the whole diet provided. Poor taste $(17.7 \%)$, food being in excess $(10.1 \%)$ and inability to eat due to their illness $(5.7 \%)$ were the reasons highlighted for failure to consume the whole diet.

The association between the overall satisfaction regarding hospital diet and the characteristics of the patients such as age, gender, ethnicity, marital status, education and length of hospital stay was assessed using Chi square test (Table 4). There was no significant association between any of the above variables and the overall quality of the hospital diet except marital status of the patients, where more unmarried persons rated quality of diet as unsatisfactory.

Table 1: Characteristics of the respondents $(n=316)$

\begin{tabular}{|c|c|}
\hline Characteristic & $\begin{array}{c}\text { Number of } \\
\text { respondents }(\%)\end{array}$ \\
\hline \multicolumn{2}{|l|}{ Gender } \\
\hline Male & $133(42.1)$ \\
\hline \multicolumn{2}{|l|}{ Age } \\
\hline Less than 18 year & $8(2.5)$ \\
\hline $19-60$ years & $176(55.7)$ \\
\hline Above 60 years & $132(41.8)$ \\
\hline \multicolumn{2}{|l|}{ Ethnicity } \\
\hline Sinhalese & $298(94.4)$ \\
\hline Tamil & $9(2.8)$ \\
\hline Moor & $9(2.8)$ \\
\hline \multicolumn{2}{|l|}{ Educational qualifications } \\
\hline Not attended to school & $33(10.4)$ \\
\hline Up to grade 5 & $60(19.0)$ \\
\hline Grade 5-11 & $120(38.0)$ \\
\hline G.C.E (O/L) & $51(16.2)$ \\
\hline G.C.E. (A/L) & $49(15.5)$ \\
\hline Diploma and degrees & $3(0.9)$ \\
\hline \multicolumn{2}{|l|}{ Monthly income } \\
\hline Economically dependant & $106(33.6)$ \\
\hline Less than Rs. 5000 & $40(12.6)$ \\
\hline Rs. $5000-10000$ & $38(12.0)$ \\
\hline Rs. $10000-20000$ & $66(20.9)$ \\
\hline More than 20000 & $66(20.9)$ \\
\hline \multicolumn{2}{|l|}{ Length of hospital stay } \\
\hline $1-7$ days & $158(50.0)$ \\
\hline 8-14 days & $69(21.8)$ \\
\hline 15 and above & $89(28.2)$ \\
\hline
\end{tabular}


Table 2: Patient perceptions regarding the adequacy of the meal provided and the percentage who consumed each food item

\begin{tabular}{|c|c|c|c|}
\hline \multirow{2}{*}{ Food Item } & \multicolumn{2}{|c|}{$\begin{array}{c}\text { Patients' perception on adequacy of } \\
\text { meals }\end{array}$} & \multirow{2}{*}{$\begin{array}{c}\text { Total No. of } \\
\text { patients who } \\
\text { consumed the } \\
\text { particular food } \\
\text { item }(\%)\end{array}$} \\
\hline & $\begin{array}{l}\text { Adequate } \\
\text { No. }(\%)\end{array}$ & $\begin{array}{l}\text { Not adequate } \\
\text { No. }(\%)\end{array}$ & \\
\hline Rice & $288(91.1)$ & $28(8.9)$ & $316(100.0)$ \\
\hline Fish & $189(85.9)$ & $31(14.1)$ & $220(69.6)$ \\
\hline Meat & Not given & & \\
\hline Egg & $207(95.8)$ & $31(4.2)$ & $238(75.3)$ \\
\hline Vegetable & $270(91.5)$ & $25(8.5)$ & $295(93.3)$ \\
\hline Green leafy vegetables & $279(94.5)$ & $16(5.5)$ & $295(93.3)$ \\
\hline Dried fish & $188(89.9)$ & $21(10.1)$ & $209(66.1)$ \\
\hline Coconut sambol & $250(83.6)$ & $49(16.4)$ & $299(94.6)$ \\
\hline
\end{tabular}

Table 3: Distribution of the level of patient satisfaction on the food service of Teaching Hospital, Karapitiya

\begin{tabular}{|c|c|c|c|c|}
\hline \multirow{2}{*}{$\begin{array}{c}\text { Aspect of hospital food } \\
\text { service }\end{array}$} & \multicolumn{3}{|c|}{ Level of satisfaction of the patients } & \multirow{2}{*}{$\begin{array}{c}\text { Not } \\
\text { answered } \\
(\%)\end{array}$} \\
\hline & $\begin{array}{c}\text { Good } \\
\text { No. }(\%) \\
\end{array}$ & $\begin{array}{c}\text { Fair } \\
\text { No. }(\%)\end{array}$ & $\begin{array}{c}\text { Unsatisfactory } \\
\text { No. }(\%)\end{array}$ & \\
\hline Taste of the food & $54(17.1)$ & $164(51.9)$ & $97(30.7)$ & $1(0.3)$ \\
\hline Smell of the food & $49(15.5)$ & $137(43.4)$ & $127(40.2)$ & $3(0.9)$ \\
\hline Texture of the food & $198(62.7)$ & $74(23.4)$ & $41(13.0)$ & $3(0.9)$ \\
\hline Varieties of food given & $96(30.4)$ & $98(31.0)$ & $93(29.4)$ & $29(9.2)$ \\
\hline Time for the food serving & $232(73.4)$ & $53(16.8)$ & $28(8.9)$ & $3(0.9)$ \\
\hline $\begin{array}{l}\text { Temperature of the food } \\
\text { received }\end{array}$ & $191(60.5)$ & $42(13.3)$ & $80(25.3)$ & $3(0.9)$ \\
\hline $\begin{array}{l}\text { Cleanliness of the spoons, } \\
\text { plates and dishes }\end{array}$ & $225(71.2)$ & $31(9.8)$ & $8(2.5)$ & $52(16.4)$ \\
\hline $\begin{array}{l}\text { Attitude and behavior of the } \\
\text { food serving staff }\end{array}$ & $216(68.4)$ & $73(23.1)$ & $22(7.0)$ & $5(1.5)$ \\
\hline $\begin{array}{l}\text { Overall quality of the food } \\
\text { service }\end{array}$ & $43(13.6)$ & $189(59.8)$ & $84(26.6)$ & $0(0.0)$ \\
\hline
\end{tabular}


Table 4: Distribution of level of satisfaction of the hospital food service according to the characteristics of the patients

\begin{tabular}{|c|c|c|c|c|}
\hline \multirow[b]{2}{*}{ Variables } & \multicolumn{3}{|c|}{ The overall quality of food service } & \multirow[b]{2}{*}{ p value } \\
\hline & $\begin{array}{c}\text { Satisfactory } \\
\text { (good/fair) } \\
\text { No. }(\%)\end{array}$ & $\begin{array}{c}\text { Unsatisfactory } \\
\text { No. }(\%)\end{array}$ & $\begin{array}{c}\text { Total } \\
\text { No. }(\%)\end{array}$ & \\
\hline \multicolumn{5}{|l|}{ Age } \\
\hline 60 years or above & $131(71.2)$ & $53(28.8)$ & $18(100.0)$ & \multirow{2}{*}{0.291} \\
\hline$<60$ year & $101(76.5)$ & $31(23.5)$ & $132(100.0)$ & \\
\hline \multicolumn{5}{|l|}{ Ethnicity } \\
\hline Sinhala & $221(74.2)$ & $77(25.8)$ & $298(100.0)$ & \multirow{2}{*}{0.224} \\
\hline Others & $11(61.1)$ & $7(38.9)$ & $18(100.0)$ & \\
\hline \multicolumn{5}{|l|}{ Educational level } \\
\hline Not schooled or below primary & $66(71.0)$ & $27(29.0)$ & $93(100.0)$ & \multirow{3}{*}{0.813} \\
\hline Grade $5-11$ & $89(74.2)$ & $31(25.8)$ & $120(100.0)$ & \\
\hline $\mathrm{O} / \mathrm{L}$ and above & $77(74.8)$ & $26(25.2)$ & $103(100.0)$ & \\
\hline \multicolumn{5}{|l|}{ Marital status } \\
\hline Married & $203(75.5)$ & $66(24.5)$ & $269(100.0)$ & \multirow{2}{*}{0.049} \\
\hline Unmarried & $29(61.7)$ & $13(38.3)$ & $42(100.0)$ & \\
\hline \multicolumn{5}{|l|}{ Economic dependency } \\
\hline Non dependent & $150(71.4)$ & $60(28.6)$ & $210(100.0)$ & \multirow[t]{2}{*}{0.260} \\
\hline Dependent & $82(77.4)$ & $24(22.6)$ & $106(100.0)$ & \\
\hline \multicolumn{5}{|l|}{ Income } \\
\hline No income & $82(77.4)$ & $24(22.6)$ & $106(100.0)$ & \multirow{3}{*}{0.455} \\
\hline Below Rs. 10000 & $54(69.2)$ & $24(30.8)$ & $78(100.0)$ & \\
\hline Above Rs.10001 & $96(72.7)$ & $36(27.3)$ & $132(100.0)$ & \\
\hline \multicolumn{5}{|l|}{ Duration of hospital stay } \\
\hline $1-7$ days & $121(76.6)$ & $37(23.4)$ & $158(100.0)$ & \multirow{3}{*}{0.115} \\
\hline 8-14 days & $53(76.8)$ & $16(23.2)$ & $63(100.0)$ & \\
\hline Above 14 days & $58(65.2)$ & $31(34.8)$ & $89(100.0)$ & \\
\hline
\end{tabular}

\section{Discussion}

The findings of this study revealed that the majority of the in-ward patients do not consume hospital food. Among patients who consume hospital diet, overall quality of food service was perceived as satisfactory by the majority. However, the taste, aroma and diversity of food were rated unsatisfactory by more participants when compared to other aspects of hospital food service.
In public health care institutions in Sri Lanka, where health care is provided free of charge, it is not unusual for the patients to perceive hospital food as an extended facility provided by the hospital, not as a part of patient management. In this study, most respondents did not consider it as a right or privilege. Therefore, some patients were of the opinion that it is not fair to comment on hospital food service. Some patients were not concerned about the quality of the food service, as they were on a short stay and some believed that they were receiving a special 
diet with less salt and spices due to their illness, therefore it is necessarily tasteless. Even though these opinions were not surveyed in a formal manner, these perceptions were voiced by the patients during the interviews.

According to our findings more female patients (58\%) were taking hospital meals. Although statistical significance of this finding could not be ascertained within the present study design, we hypothesize that it could be a reflection of the prevailing cultural practice, where females bear the sole responsibility in food preparation. As a result, when male patients are admitted, usually the female partners provide home-made food for them. However, when females are admitted, their male partners are not capable of providing homecooked meals and thus, they are compelled to eat hospital food. In a similar study conducted in United Kingdom, Li-Jene et al. reported that the consumption of hospital meal is more in females (14), although Kim and colleague found no difference in hospital meal consumption with regards to sex of the patients (11).

Majority (55.7\%) of patients taking hospital meals in this sample were between 19-60 yrs. As most of the in-ward patients are likely to be in this age group our sample is likely to be representative sample of hospital in-ward patients. The demographic pattern in Sri Lanka also indicates that a higher percentage of persons are found in this age group (15). The least number of patients were in less than 18 years age group. Patients of this age category are mostly dependents and these patients are frequently visited by their family members. This may be the reason for them not to accept hospital foods. Li-Jen et al. reported that hospital food consumption is higher in the oldest age group (14). Kim and co-workers reported that the consumption rates are not significantly different between age groups (11).

Interestingly, only one third of patients who were taking hospital food were economically dependent. Contrary to the popular belief that hospital diets are consumed by the poor, this indicates that even people with a regular income are willing to consume hospital diet. This exerts a positive impression toward the hospital diet.

In this study, more than $80 \%$ of patients said that they were satisfied with the quantity of all food items provided. Most of subjects were satisfied with the texture, time of delivery and temperature of the meal but the proportion satisfied with the taste, aroma and variety of food was lower. Studies conducted in Canada and Saudi Arabia have reported similar results $(9,16)$.

With regards to delivery of meals, most consumers were satisfied with the cleanliness of utensils, timeliness of distribution of food and the attitudes and behaviour of serving staff. More than $90 \%$ mentioned that the attitudes of the staff were good or satisfactory. However, this could be due to the reluctance of the patients to make any adverse comment on the hospital staff for the fear that it might affect their hospital care. Although a selfadministered questionnaire would have been the ideal method for data collection, during the pilot study it was found that the response rate was poor with this method.

Overall satisfaction towards the hospital meal was very low with only $13.6 \%$ of patients rating that food service was good. Although the majority rated it as fair, a considerable proportion of the study sample $(26.6 \%)$ were unsatisfied with overall food service. Although these results are in accordance with the existing findings (17), a closer look at consumer satisfaction with respect to different aspects of food service reveals interesting complexities.

According to this study, cleanliness, time of food distribution and attitudes of staff are not in keeping with the overall satisfaction of the meal. The majority of patients rated these aspects as good, despite stating that overall food service was fair or unsatisfactory. According to Li-Jen et al. timeliness is strongly associated with patient satisfaction on meal (14). Dube et al. also have reported the same finding (18). However, in this population, taste and aroma of food seem to be the major determinant of the overall satisfaction. Any food service aiming to enhance consumer satisfaction should focus on improving the palatability of meals and making them more appetizing, in addition to providing food in a timely and hygienic manner.

The evaluation of association between overall satisfaction of hospital food service and the characteristics of the patients failed to demonstrate any significant findings. Both Li-Jen et al. and O' Hara et al. reported that there is no association 
between patients' perception of meal and age, gender, length of stay and the gross income $(9,14)$. On the contrary, Dube et al. confirmed that such individual characteristics influenced perception of hospital food (18).

This study has a few limitations. We could not exclude response bias due to the tendency of respondents to give favorable responses regarding the diet, because the interviewer was a medical officer. However, such patients would have only voiced favourable responses, thus it cannot explain the high levels of dissatisfaction seen among the participants. In addition, some patients were consuming hospital diet on an irregular basis. The perception of those patients would not have been comparable to those who consumed meals regularly, although both groups were considered together in assessing overall satisfaction with food service. The third source of bias relates to the current illnesses and the treatments of participants, which may have affected the appetite and the taste for foods, interfering with their appraisal.

\section{Conclusion}

The patient perception on the hospital food service at TH Karapitiya was fair. The rate of hospital food consumption was considerably low. Attempts need to be taken to enhance the taste, smell and the diversity of food provided. Regular supervision and 'surprise observations' must be conducted to maintain the standards of food service. Continuous monitoring and evaluations must be carried out including consumer surveys in order to identify the areas needing improvement. Norms should be developed regarding the food services of the hospitals.

\section{Acknowledgements}

Authors are grateful to the Director, TH, Karapitiya for cooperation and support. The commitment of the volunteers who took part in the survey is deeply appreciated.

No financial support was involved and the authors declare no conflicts of interest in conducting this research or publishing of the manuscript.

\section{References}

1. McLymont V, Sharon C, Stell F. Improving patient meal satisfaction with room service meal delivery. Journal of Nursing Care Quality, 2003;18(1): 27-37.

2. Hartwell H, Edwards JSA. A preliminary assessment of two hospital food service systems using parameters of food safety and consumer opinion. The Journal of the Royal Society for the Promotion of Health, 2001; 121: 236-42.

3. Williams R, Virtue K, Adkins A. Room service improves patient food intake and satisfaction with hospital food. Journal of Pediatric Oncology Nursing, 1998; 15(3): 183-9.

4. Theurer VA. Improving patient satisfaction in a hospital cfood service system using low-cost interventions: determining whether a room service system is the next step. All Graduate Reports and Creative Projects, 2011;32: 6.

5. Wright OR, Connelly LB, Capra S. Consumer evaluation of hospital food service quality: an empirical investigation. International Journal of Health Care Quality Assurance Incorporating Leadership in Health Services 2006; 19(2-3): 181-94.

6. Fallon A, Gurrs S, Hannan-Jones M, Bauer JD. Use of the Acute Care Hospital Food service Patient Satisfaction Questionnaire to monitor trends in patient satisfaction with food service at an acute care private hospital. Nutrition \& Dietetics, 2008; 65: 4146. doi: 10.1111/j.1747-0080.2007. 00219 .

7. Alford L. Hospital Food Review: Sourcing more local and sustainable food. 2010. Pp2.http://www.soilassociation.Org /LinkClick.aspx?fileticket=qf0jvMzz26U\%3D\&tabid=131 (last accessed on $29^{\text {th }}$ Sep 2015).

8. Jung SH, Yeom HS, Sohn CM. The improvement of hospital food service in quality and customer satisfaction by using 6sigma strategy. Journal of the Korean Dietetic Association, 2007; 13:331-4.

9. O'Hara PA, Harper DW, Kangas M, Bubeau J, Borsutzky C, Lemire N. Taste, temperature, and presentation predict satisfaction with food services in a Canadian continuing care hospital. Journal of American Dietetic Association, 1997; 97: 401-5.

10. Lim HS, Yang IS, Cha JA. Analysis of patient satisfaction and factors influencing satisfaction on hospital food service quality. Journal of the Korean Dietetic Association, 1999; 5 : 29-47. 
11. Kim YS, Lyu ES. Evaluation of patients' satisfaction with food service of mid-size hospitals in Busan area. Journal of the Korean Society of Food Science and Nutrition, 2003; 32: 1153-6.

12. Kim MY, Kim KJ, Lee KE. In-patients' food consumption and perception on foodservice quality at hospitals. Journal of the Korean Dietetic Association, 2008; 13: 87-96.

13. Ministry of Health. Manual of management of teaching, provincial, base, and special hospital, ministry of health: Diet service 1995; Ministry of Health. 442-58.

14. Li-jene, Anita E, Dosomdre T. Gap analysis of patient meal service perception, International Journal of Health Assurance, 2003; 16(3): 143-153.

15. Census and statistics department. Http://www.indexmundi. Com/sri_lanka/demographics_profile.html. Sri Lanka Demographics Profile 2013. (last accessed on $29^{\text {th }}$ Sep 2015).
16. Abdelhafez AM, Qurashi LA, Ziyadi RA, Kuwair A, Mograbi MSH. Analysis of factors affecting the satisfaction level of patients towards food services at general hospitals in Makkah, Saudi Arabia. American Journal of Medicine and Medical Sciences, 2012;2(6): 123-30.

17. Kulkarnil MV, Dasgupt S, Deoke AR, Nayse. Study of satisfaction of patients admitted in a tertiary care hospital in Nagpur. National Journal of Community Medicine, 2011; 2(1):37-9.

18. Dube L, Trudeau E, Belenger M. Determining the complexity of patient satisfaction with food services. Journal of the American Diabetic Association, 1994; 94: 394-8. 